\title{
Synthesis, Crystal Structures, and Magnetic Properties of One-dimensional Lanthanide(III)-Octacyanomolybdate(V) Assemblies with 3,4,7,8-Tetramethyl-1,10-phenanthroline as a Blocking Ligand
}

\author{
Jun Wang

\begin{abstract}
Department of Chemistry, Yancheng Teachers' College, Yancheng 224002, P.R. China. E-mail: wjyctu@gmail.com Received August 2, 2013, Accepted August 10, 2013
\end{abstract}

\begin{abstract}
Key Words : Octacyanometalates, Rare earth metals, Crystal structures, Magnetic properties, One dimensional complexes
\end{abstract}

The study of molecular magnets is a hot topic in the field of material science because of its promising application in the future. Cyanide is usually applied as a bridging ligand between spin carriers, which is due to the fact that cyanide can mediate foreseeable magnetic coupling interaction. Recently, cyano-bridged bimetallic systems based on octacyanometalates $\left[\mathrm{M}^{\mathrm{IV}(\mathrm{V})}(\mathrm{CN})_{8}\right]^{4-(3-)}(\mathrm{M}=\mathrm{Mo}, \mathrm{W}$ and $\mathrm{Nb})$ have attracted great attention in molecular magnetism because of their interesting and special properties. ${ }^{1,2}$ Comparing to the widely investigated hexacyanometalate, the octacyanometalate building blocks are more versatile due to more spatial configurations (e.g., square antiprism $\left(D_{4 d}\right)$, dodecahedron $\left(D_{2 d}\right)$ and bicapped trigonal prism $\left.\left(C_{2 v}\right)\right)$, so that the octacyanometallate-based complexes show rich magnetic properties from low-dimensional magnets (SMMs and SCMs) ${ }^{3}$ to long-range ordered magnets. ${ }^{4-6}$ On the other hand, lanthanide ions have been widely used in the field of molecular magnets because of its considerable single ion anisotropy and high spin numbers. ${ }^{7}$ Furthermore, the lanthanide ions often have high coordination numbers, so the complexes containing lanthanide ions may have a lot of very complicated structures, further show interesting magnetic properties. ${ }^{8,9}$ Therefore, the association of lanthanide with paramagnetic octacyanometalate building blocks seems to be an interesting way in the field of molecular magnets. In fact, the investigation of octacyanometalate-based bimetallic systems has mainly focused on first-row transition-metal ions ${ }^{10,11}$ and there are a few of coordination complexes containing octacyanometallates and lanthanide ions. $.^{12-14} 3,4,7,8$ - tetramethyl1,10-phenanthroline (tmphen) as a blocking ligand has been used in the construction of hexacyanometalate-based lowdimensional magnets. ${ }^{15,16}$ Similarly, we choose tmphen as the additional ligand to obtain two 1D lanthanide octacyanometalate-based metal assemblies, [Ln(tmphen $)_{2}(\mathrm{DMF})_{2}-$ $\left.\mathrm{Mo}(\mathrm{CN})_{8}\right](\mathrm{Ln}=\mathrm{Tb}(1)$ and $\mathrm{Dy}(2), \mathrm{DMF}=N, N$-dimethylformamide). Herein, the synthesis, structures, and magnetic properties are reported.

\section{Experimental Section}

Materials and Physical Measurements. The reagent 3,4,7,8-tetramethyl-1,10-phenanthroline (tmphen) was pur- chased from Aldrich and used without further purification. $\mathrm{Cs}_{3}\left[\mathrm{~W}(\mathrm{CN})_{8}\right] \cdot 2 \mathrm{H}_{2} \mathrm{O}$ was prepared according to literature. ${ }^{17}$ All other reagents were commercial available and used as received. Infrared spectra were obtained within the 4000$400 \mathrm{~cm}^{-1}$ as $\mathrm{KBr}$ disks on a VECTOR 22 spectrometer. Elemental analyses were performed on a Perkin Elmer 240C elemental analyzer. Magnetic measurements on microcrystalline sample were carried out on a Quantum Design MPMP-XL7 superconducting quantum interference device (SQUID) magnetometer. Diamagnetic corrections were made for both the sample holder as the background and the compound estimated from Pascal's constants. ${ }^{18}$

Synthesis of Complexes 1-2. To a solution of $\mathrm{Tb}\left(\mathrm{NO}_{3}\right)_{3} \cdot 6 \mathrm{H}_{2} \mathrm{O}$ $(0.1 \mathrm{mmol}, 45.3 \mathrm{mg})$ or $\mathrm{Dy}\left(\mathrm{NO}_{3}\right)_{3} \cdot 6 \mathrm{H}_{2} \mathrm{O}(0.1 \mathrm{mmol}, 45.6$ $\mathrm{mg})$ and $\mathrm{Cs}_{3}\left[\mathrm{Mo}(\mathrm{CN})_{8}\right] \cdot 4 \mathrm{H}_{2} \mathrm{O}(15.5 \mathrm{mg}, 0.02 \mathrm{mmol})$ in $\mathrm{H}_{2} \mathrm{O}$ $(5 \mathrm{~mL})$, a solution of tmphen $(4.7 \mathrm{mmol}, 0.02 \mathrm{mmol})$ in $\mathrm{CH}_{3} \mathrm{CN}(2 \mathrm{~mL})$ was added dropwise with gentle stirring. The yellow precipitate was dissolved using $c a .2 \mathrm{~mL}$ of DMF. The resulting solution mixture was allowed to stand in the dark without disturbance for several weeks and red prism single crystals suitable for X-ray analysis were obtained.

Complex 1: Yield $8.9 \mathrm{mg}(41.1 \%)$. Calculated for $\mathrm{C}_{46} \mathrm{H}_{46} \mathrm{~N}_{14} \mathrm{O}_{2} \mathrm{MoTb}$ : C, 51.07\%; H, 4.29\%; N, 18.13\%. Found: C, 51.15\%; H, 4.30\%; N, 18.32\%, IR stretching cyanide $(\mathrm{KBr}) / \mathrm{cm}^{-1}: 2118,2160$.

Complex 2: Yield $9.1 \mathrm{mg}(41.9 \%)$. Calculated for $\mathrm{C}_{46} \mathrm{H}_{46} \mathrm{~N}_{14} \mathrm{O}_{2} \mathrm{MoDy}$ : C, 50.90\%; H, 4.27\%; N, 18.07\%. Found: C, 50.84\%; H, 4.26\%; N, 17.91\%, IR stretching cyanide $(\mathrm{KBr}) / \mathrm{cm}^{-1}: 2121,2154$.

Structural Determination and Refinement. The crystal structures were determined on a Siemens (Bruker) SMART $\mathrm{CCD}$ diffractometer using monochromated Mo-K $\alpha$ radiation $(\lambda=0.71073 \AA)$ at room temperature. All absorption corrections were performed by using the SADABS program. ${ }^{19}$ Structures were solved by direct methods using the program SHELXL-97. ${ }^{20}$ All non-hydrogen atoms were located in difference Fourier maps and refined anisotropically. All H atoms were refined isotropically, with the isotropic vibration parameters related to the non- $\mathrm{H}$ atom to which they are bonded. A summary of the structural determination and refinement for the title complexes 1-2 is listed in Table 1 and the selected bond distances and angles are shown in Tables 
Table 1. Crystal and experimental data of complexes 1-2

\begin{tabular}{lll}
\hline Complex & $\mathbf{1}$ & $\mathbf{2}$ \\
\hline Empirical formula & $\mathrm{C}_{46} \mathrm{H}_{46} \mathrm{~N}_{14} \mathrm{O}_{2} \mathrm{MoTb}$ & $\mathrm{C}_{46} \mathrm{H}_{46} \mathrm{~N}_{14} \mathrm{O}_{2} \mathrm{MoDy}$ \\
\hline Formula weight & 1081.84 & 1085.41 \\
Crystal system & Orthorhombic & Orthorhombic \\
Space group & $\mathrm{P} b c a$ & $\mathrm{P} b c a$ \\
$a / \AA$ & $16.643(1)$ & $16.448(1)$ \\
$b / \AA$ & $21.637(2)$ & $21.738(2)$ \\
$c / \AA$ & $25.518(2)$ & $25.410(2)$ \\
$\alpha /{ }^{\circ}$ & 90.00 & 90.00 \\
$\beta /{ }^{\circ}$ & 90.00 & 90.00 \\
$\gamma /{ }^{\circ}$ & 90.00 & 90.00 \\
$V / \AA^{3}$ & $9189(1)$ & $9085(1)$ \\
$Z$ & 8 & 8 \\
$D_{\text {calc }} / \mathrm{g} \cdot \mathrm{m}^{-3}$ & 1.564 & 1.587 \\
$F(000)$ & 4344 & 4352 \\
Limits of data collection $/{ }^{\circ}$ & $1.74 \leq \theta \leq 26.00$ & $1.60 \leq \theta \leq 25.00$ \\
Reflections collected & 47344 & 46657 \\
Independent reflections $\left(R_{\text {int }}\right)$ & $9023(0.0936)$ & $7988(0.0901)$ \\
Goodness of fit & 1.112 & 1.077 \\
$R$ indices $(I>2 \sigma(I))$ & $R_{1}=0.0519$, & $R_{1}=0.0453$, \\
& $w R_{2}=0.1220$ & $w R_{2}=0.1163$ \\
$R$ indices (all data) & $R_{1}=0.0627$, & $R_{1}=0.0764$, \\
& $w R_{2}=0.1276$ & $w R_{2}=0.1359$ \\
$R_{1}=\Sigma|| F_{\mathrm{o}}|-| F_{\mathrm{c}}|/ \Sigma| F_{\mathrm{o}} \mid . \omega R_{2}=\Sigma\left[w\left(F_{\mathrm{o}}{ }^{2}-F_{\mathrm{c}}{ }^{2}\right)^{2}\right] / \Sigma\left[w\left(F_{\mathrm{o}}{ }^{2}\right)^{2}\right]^{1 / 2}$
\end{tabular}

Table 2. Selected bond distances $(\AA)$ and angles $\left({ }^{\circ}\right)$ for $\mathbf{1}$

\begin{tabular}{llll}
\hline $\mathrm{Mo}(1)-\mathrm{C}(1)$ & $2.150(5)$ & $\mathrm{Mo}(1)-\mathrm{C}(2)$ & $2.152(6)$ \\
$\mathrm{Mo}(1)-\mathrm{C}(3)$ & $2.169(7)$ & $\mathrm{Mo}(1)-\mathrm{C}(4) \# 2$ & $2.145(5)$ \\
$\mathrm{Mo}(1)-\mathrm{C}(5)$ & $2.162(7)$ & $\mathrm{Mo}(1)-\mathrm{C}(6)$ & $2.145(7)$ \\
$\mathrm{Mo}(1)-\mathrm{C}(7)$ & $2.150(6)$ & $\mathrm{Mo}(1)-\mathrm{C}(8)$ & $2.166(7)$ \\
$\mathrm{Tb}(1)-\mathrm{O}(1)$ & $2.313(4)$ & $\mathrm{Tb}(1)-\mathrm{O}(2)$ & $2.329(4)$ \\
$\mathrm{Tb}(1)-\mathrm{N}(1)$ & $2.476(4)$ & $\mathrm{Tb}(1)-\mathrm{N}(4)$ & $2.478(4)$ \\
$\mathrm{Tb}(1)-\mathrm{N}(9)$ & $2.546(4)$ & $\mathrm{Tb}(1)-\mathrm{N}(10)$ & $2.550(5)$ \\
$\mathrm{Tb}(1)-\mathrm{N}(11)$ & $2.559(4)$ & $\mathrm{Tb}(1)-\mathrm{N}(12)$ & $2.557(4)$ \\
$\mathrm{N}(1)-\mathrm{C}(1)-\mathrm{Mo}(1)$ & $176.0(5)$ & $\mathrm{N}(2)-\mathrm{C}(2)-\mathrm{Mo}(1)$ & $176.6(6)$ \\
$\mathrm{N}(3)-\mathrm{C}(3)-\mathrm{Mo}(1)$ & $178.6(6)$ & $\mathrm{N}(4)-\mathrm{C}(4)-\mathrm{Mo}(1) \# 1$ & $178.9(5)$ \\
$\mathrm{N}(5)-\mathrm{C}(5)-\mathrm{Mo}(1)$ & $179.3(7)$ & $\mathrm{N}(6)-\mathrm{C}(6)-\mathrm{Mo}(1)$ & $178.4(6)$ \\
$\mathrm{N}(7)-\mathrm{C}(7)-\mathrm{Mo}(1)$ & $178.1(6)$ & $\mathrm{N}(8)-\mathrm{C}(8)-\mathrm{Mo}(1)$ & $176.9(7)$ \\
$\mathrm{C}(1)-\mathrm{N}(1)-\mathrm{Tb}(1)$ & $166.7(4)$ & $\mathrm{C}(4)-\mathrm{N}(4)-\mathrm{Tb}(1)$ & $176.8(5)$ \\
\hline
\end{tabular}

Symmetry transformations used to generate equivalent atoms: $1-x+3 / 2$, $\mathrm{y}+1 / 2, \mathrm{z} ; \# 2-\mathrm{x}+3 / 2, \mathrm{y}-1 / 2, \mathrm{z}$.

$2-3$.

\section{Results and Discussions}

Crystal Structures of Complexes 1-2. Complexes 1-2 have the same structural skeleton with the orthorhombic space group $\mathrm{Pbca}$, we only depict the crystal structure of complex 1 in detail. As shown in Figure 1, the asymmetric unit of complex 1 consists of a $\left[\mathrm{Tb}(\text { tmphen })_{2}(\mathrm{DMF})_{2}\right]^{3+}$ and a $\left[\mathrm{Mo}(\mathrm{CN})_{8}\right]^{3-}$. The eight coordination environment around $\mathrm{Tb}$ ion is composed of two tmphen, two DMF molecules and two bridging cyanide ligands forming a distorted square
Table 3. Selected bond distances $(\AA)$ and angles $\left({ }^{\circ}\right)$ for $\mathbf{2}$

\begin{tabular}{llll}
\hline $\mathrm{Mo}(1)-\mathrm{C}(1)$ & $2.165(7)$ & $\mathrm{Mo}(1)-\mathrm{C}(2)$ & $2.165(7)$ \\
$\mathrm{Mo}(1)-\mathrm{C}(3)$ & $2.145(8)$ & $\mathrm{Mo}(1)-\mathrm{C}(4)$ & $2.162(8)$ \\
$\mathrm{Mo}(1)-\mathrm{C}(5)$ & $2.164(7)$ & $\mathrm{Mo}(1)-\mathrm{C}(6)$ & $2.162(7)$ \\
$\mathrm{Mo}(1)-\mathrm{C}(7)$ & $2.142(8)$ & $\mathrm{Mo}(1)-\mathrm{C}(8)$ & $2.155(8)$ \\
$\mathrm{Dy}(1)-\mathrm{O}(1)$ & $2.277(5)$ & $\mathrm{Dy}(1)-\mathrm{O}(2)$ & $2.311(5)$ \\
$\mathrm{Dy}(1)-\mathrm{N}(1)$ & $2.464(5)$ & $\mathrm{Dy}(1)-\mathrm{N}(5) \# 1$ & $2.459(6)$ \\
$\mathrm{Dy}(1)-\mathrm{N}(9)$ & $2.520(5)$ & $\mathrm{Dy}(1)-\mathrm{N}(10)$ & $2.507(5)$ \\
$\mathrm{Dy}(1)-\mathrm{N}(11)$ & $2.538(5)$ & $\mathrm{Dy}(1)-\mathrm{N}(12)$ & $2.537(5)$ \\
$\mathrm{N}(1)-\mathrm{C}(1)-\mathrm{Mo}(1)$ & $176.1(6)$ & $\mathrm{N}(2)-\mathrm{C}(2)-\mathrm{Mo}(1)$ & $178.0(7)$ \\
$\mathrm{N}(3)-\mathrm{C}(3)-\mathrm{Mo}(1)$ & $179.9(8)$ & $\mathrm{N}(4)-\mathrm{C}(4)-\mathrm{Mo}(1)$ & $178.7(7)$ \\
$\mathrm{N}(5)-\mathrm{C}(5)-\mathrm{Mo}(1)$ & $178.7(6)$ & $\mathrm{N}(6)-\mathrm{C}(6)-\mathrm{Mo}(1)$ & $175.9(6)$ \\
$\mathrm{N}(7)-\mathrm{C}(7)-\mathrm{Mo}(1)$ & $176.6(7)$ & $\mathrm{N}(8)-\mathrm{C}(8)-\mathrm{Mo}(1)$ & $179.2(6)$ \\
$\mathrm{C}(1)-\mathrm{N}(1)-\mathrm{Dy}(1)$ & $167.4(5)$ & $\mathrm{C}(5)-\mathrm{N}(5)-\mathrm{Dy}(1) \# 2$ & $177.3(5)$ \\
\hline
\end{tabular}

Symmetry transformations used to generate equivalent atoms: $\# 1-\mathrm{x}+3$ / $2, y+1 / 2, z ; \# 2-x+3 / 2, y-1 / 2, z$.

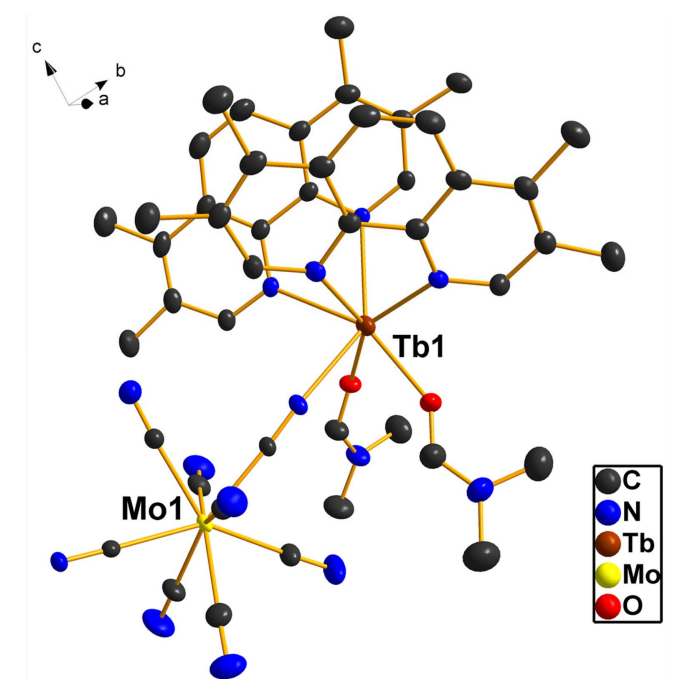

Figure 1. ORTEP drawing of the asymmetrical unit of $\mathbf{1}$ with atomic labeling for metal ions and donor atoms. Displacement ellipsoids are drawn at 30\% probability level. Hydrogen atoms have been omitted for clarity.

anti-prism. Two tmphen and two DMF molecules coordinate to $\mathrm{Tb}$ ion on two sides, and the tmphen molecules stabilize the structure by intramolecule $\pi-\pi$ stacking effect. The Tb$\mathrm{N}_{\text {tmphen }}$ bond lengths range from 2.546(4) to 2.559(4) $\AA$, the $\mathrm{Tb}-\mathrm{N}_{\mathrm{CN}}$ from 2.476(4) to 2.478(4) $\AA$, and the $\mathrm{Tb}-\mathrm{O}_{\mathrm{DMF}}$ distances are slightly shorter in the range of 2.313(4)$2.329(4) \AA$. The $\mathrm{Tb}-\mathrm{N} \equiv \mathrm{C}$ linkages are poorly linear with the angles of 166.7(4) and 176.8(5) $\AA$. In all complexes 1-2, the bond lengths and angles related to lanthanide ions are in good agreement with those in the reported literature. ${ }^{15 b}$ $\mathrm{Mo}^{\mathrm{V}}(\mathrm{CN})_{8}$ takes a slightly distorted square anti-prism geometry, in which two cyanides (C1N1 and C4N4) connect to the two neighboring $\left[\mathrm{Tb}(\text { tmphen })_{2}(\mathrm{DMF})_{2}\right]^{3+}$ units by cisoid mode to form a chain structure, while the other cyanides are terminal. The Mo-CN bond lengths range from 2.145(5) to $2.169(7) \AA$, the $\mathrm{C} \equiv \mathrm{N}$ from $1.132(8)$ to $1.151(8) \AA$, and the $\mathrm{Mo}-\mathrm{C} \equiv \mathrm{N}$ linkages are almost linear from $176.0(5)^{\circ}$ to $179.3(7)^{\circ}$. For complex 2, the Mo-CN bond lengths range 


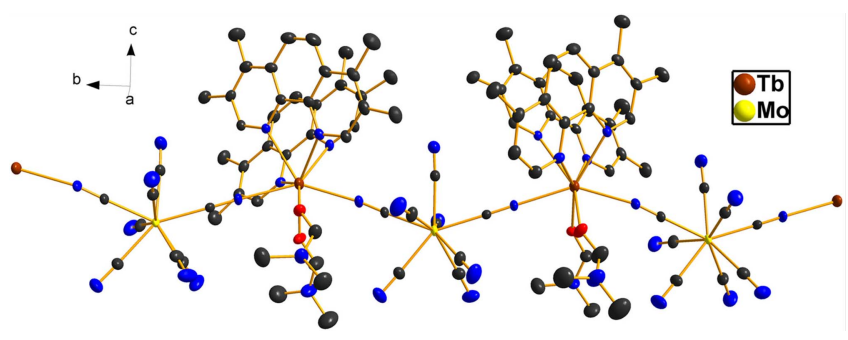

Figure 2. The 1D infinite structure of $\mathbf{1}$ along $b c$ plane. Hydrogen atoms have been omitted for clarity.

from 2.142(8) to 2.165(7) $\AA$, the $\mathrm{C} \equiv \mathrm{N}$ from 1.143(9) to $1.162(9) \AA$, and the Mo- $\mathrm{C} \equiv \mathrm{N}$ linkages are from $175.9(6)^{\circ}$ to $179.9(8)^{\circ}$. All bond lengths and angles based $\mathrm{Mo}(\mathrm{CN})_{8}$ in complexes 1-2 are comparable with those in reported literatures. ${ }^{3-6}$

In complex 1, $\left[\mathrm{Tb}(\text { tmphen })_{2}(\mathrm{DMF})_{2}\right]^{3+}$ and $\left[\mathrm{Mo}(\mathrm{CN})_{8}\right]^{3-}$ ions are linked in an alternating fashion to form a 1D cyanobridged chain as shown in Figure 2. In a unit cell, four equivalent chains separate from each other with a minimum intermetallic distance between $\mathrm{Tb}$ and Mo of $11.348 \AA$. The intramolecular distances $\mathrm{Tb}-\mathrm{Mo}$ is $5.719 \AA$ ( Tb-C1 $\equiv \mathrm{N} 1$ $\mathrm{Mo})$ and $5.758 \AA$ (Tb-C4=N4-Mo). The Mol-Tb-Mo1 angle is $140.99^{\circ}$ for 1 , which is an indication of the zig-zag chain structure. In the solid state, the neighboring $\left\{\mathrm{Tb}^{\mathrm{III}} \mathrm{Mo}^{\mathrm{V}}\right\}_{n}$ chains weakly interact through the face-to-face $\pi-\pi$ stacking of the tmphen aromatic rings, leading to the $2 \mathrm{D}$ supramolecular folded layer. However, no hydrogen bonding is observed, so the structure of the solid state for complex $\mathbf{1}$ is stabilized mainly by van der Waals forces.

Magnetic Properties of Complex 1-2. In lanthanide complexes, the spin-orbital coupling leads to the $4 \mathrm{f}^{\mathrm{n}}$ configuration splitting into ${ }^{2 S+1} L_{J}$ states, and further into Stark components under the crystal-field perturbation. So, usually, the variable-temperature magnetic behavior of lanthanidebased complexes mainly arises from the significant orbital contributions of $\mathrm{Ln}^{\mathrm{III}}$ ions (with the exception of $\mathrm{Gd}^{\mathrm{III}}$ ). Above room temperature, all of the Stark levels are populated, but as the temperature decreases, the effective magnetic moment of the lanthanide ion will change as a result of thermal depopulation of the Stark sublevels.

For $1, \chi_{\mathrm{M}} T$ slowly decreases from $12.28 \mathrm{~cm}^{3} \mathrm{~K} \mathrm{~mol}^{-1}$ at $300 \mathrm{~K}$ (spin-only values of $11.815 \mathrm{~cm}^{3} \mathrm{~K} \mathrm{~mol}^{-1}$ for isolated $\operatorname{Tb}^{\text {III }}(J=6, g=3 / 2)$ and $0.375 \mathrm{~cm}^{3} \mathrm{~K} \mathrm{~mol}^{-1}$ for $\mathrm{Mo}^{\mathrm{V}}(S=1 / 2$, $g=2)$ ) to a minimum of $9.40 \mathrm{~cm}^{3} \mathrm{~K} \mathrm{~mol}^{-1}$ at $5 \mathrm{~K}$, which is mainly ascribed to the depopulation of the Stark levels of the terbium ${ }^{7} \mathrm{~F}_{6}$ ground state. Upon cooling, the value increases to a maximum of $10.06 \mathrm{~cm}^{3} \mathrm{~K} \mathrm{~mol}^{-1}$ at $1.8 \mathrm{~K}$, which indicates that the coupling interaction between metal ions overcomes the depopulation of the ground state leading to a net spin along the field, but cannot draw a conclusion about the magnetic coupling nature. The variable-field magnetic properties show that the magnetization undiversified increases with the external field and goes up to $5.69 N \mu_{\mathrm{B}} \mathrm{mol}^{-1}$ at $7 \mathrm{~T}$ which is consistent with the ferromagnetic ground state spin based on a spin of $S=1 / 2$ with $g=2$ for $\mathrm{Mo}^{\mathrm{V}}$ ion and an effective spin

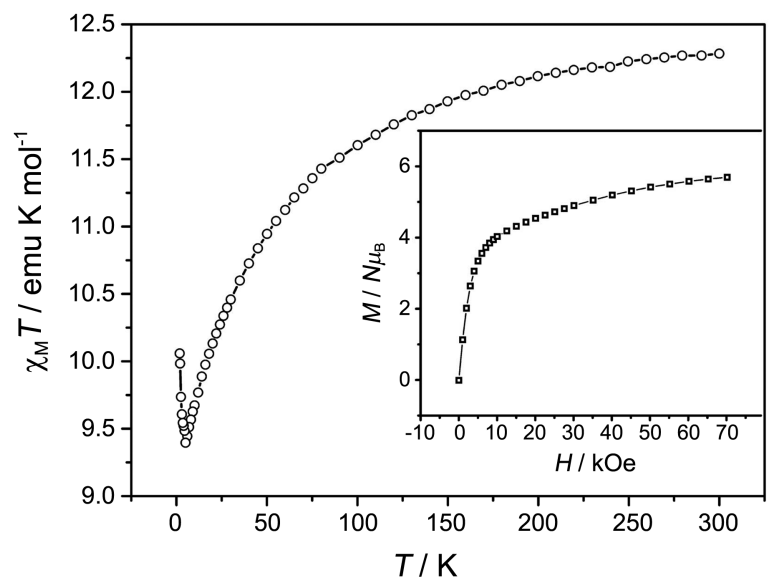

Figure 3. Temperature dependence of the $\chi_{M} T$ product for $\mathbf{1}$ at 100Oe. The inset shows the magnetization versus the applied magnetic field at $1.8 \mathrm{~K}$.

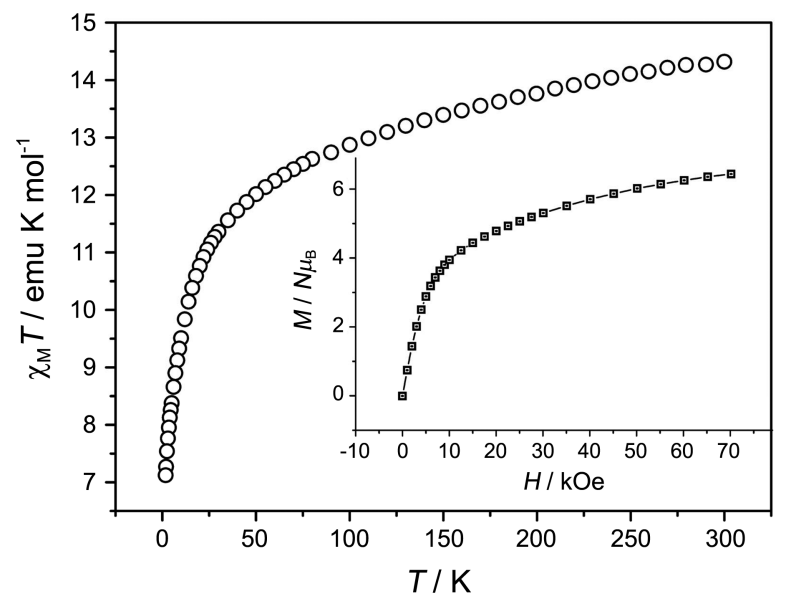

Figure 4. Temperature dependence of the $\chi_{M} T$ product for 2 at $100 \mathrm{Oe}$. The inset shows the magnetization versus the applied magnetic field at $1.8 \mathrm{~K}$.

of $S=1 / 2$ with $\mathrm{g}_{\|}=10$ and $\mathrm{g}_{\perp}=0$ for $\mathrm{Tb}^{\mathrm{III}}$ ion. ${ }^{6,12-14} \mathrm{So}$, it is suggested that the cyano-bridge mediates the ferromagnetic interaction between $\mathrm{Mo}^{\mathrm{V}}$ and $\mathrm{Tb}^{\mathrm{III}}$ ions.

For 2, the $\chi_{\mathrm{M}} T$ value is $14.32 \mathrm{~cm}^{3} \mathrm{~K} \mathrm{~mol}^{-1}$ at the room temperature, slightly lower than the sum of the spin-only values of $14.145 \mathrm{~cm}^{3} \mathrm{~K} \mathrm{~mol}^{-1}$ expected for isolated $\mathrm{Dy}^{\mathrm{III}}$ and $0.375 \mathrm{~cm}^{3} \mathrm{~K} \mathrm{~mol}^{-1}$ for $\mathrm{Mo}^{\mathrm{v}}$. Upon cooling, $\chi_{\mathrm{M}} T$ value invariantly decreases and reaches $7.12 \mathrm{~cm}^{3} \mathrm{~K} \mathrm{~mol}^{-1}$ at $1.8 \mathrm{~K}$ (Figure 4). The variable-field magnetic properties show that the magnetization monotonously increases with the external field and goes up to $6.44 N \mu_{\mathrm{B}} \mathrm{mol}^{-1}$ at $7 \mathrm{~T}$, indicating that the cyano-bridge also mediates the ferromagnetic interaction between $\mathrm{Mo}^{\mathrm{V}}$ and Dy ${ }^{\mathrm{III}}$ ions $(1+5.23) N \mu_{\mathrm{B}}{ }^{21}$ No increase of $\chi_{\mathrm{M}} T$ observed at low temperature like that of complex 2 implies that the ferromagnetic interaction is very weak relative to the depopulation of the Stark levels of the Dy ${ }^{\mathrm{II}}$ ion.

In conclusion, we report here the synthesis, structures, and magnetic characterization of two new one-dimensional cyano-bridged coordination polymers $\left[\mathrm{Ln}(\mathrm{tmphen})_{2}(\mathrm{DMF})_{2}-\right.$ 
$\left.\mathrm{Mo}(\mathrm{CN})_{8}\right]_{\infty}(\mathrm{Ln}=\mathrm{Tb}(\mathbf{1})$ and $\operatorname{Dy}(\mathbf{2}))$. Two complexes are isostructural and crystallize in the orthorhombic space group $\mathrm{Pbca}$. Magnetic investigations show that the ferromagnetic interaction exists in complexes 1-2.

Supplementary Material. CCDC-836416(1) and 836411 (2) contain the supplementary crystallographic data for this paper. These data can be obtained free of charge via http:// www.ccdc.cam.ac.uk/conts/retrieving.html [or from the Cambridge Crystallographic Data Centre, 12 Union Road, Cambridge, CB2 1EZ, UK; Telephone: (44) 01223 762910; Facsimile: (44) 01223 336033; E-mail: deposit@ccdc.cam. ac.uk].

Acknowledgments. The publication cost of this paper was supported by the Korean Chemical Society.

\section{References}

1. (a) Sieklucka, B.; Podgajny, R.; Przychodzeń, P.; Korzeniak, T. Coord. Chem. Rev. 2005, 249, 2203. (b) Sieklucka, B.; Podgajny, R.; Pinkowicz, D.; Nowicka, B.; Korzeniak, T.; Bałanda, M.; Wasiutyński, T.; Pełka, R.; Makarewicz, M.; Czapla, M.; Rams, M.; Gaweł, B.; Łasocha, W. CrystEngComm 2009, 11, 2032.

2. (a) Sieklucka, B.; Podgajny, R.; Korzeniak, T.; Nowicka, B.; Pinkowicz, D.; Kozieł, M. Eur. J. Inorg. Chem. 2011, 305. (b) Nowicka, B.; Korzeniak, T.; Stefańczyk, O.; Pinkowicz, D.; Chorąży, S.; Podgajny, R.; Sieklucka, B. Coord. Chem. Rev. 2012, 256, 1946.

3. (a) Song, Y.; Zhang, P.; Ren, X.-M.; Shen, X.-F.; Li, Y.-Z.; You, X.-Z. J. Am. Chem. Soc. 2005, 127, 3708. (b) Lim, J. H.; Yoon, J. H.; Kim, H. C.; Hong, C. S. Angew. Chem. Int. Ed. 2006, 45, 7424.

4. (a) Zhong, Z. J.; Seino, H.; Mizobe, Y.; Hidai, M.; Verdaguer, M.; Ohkoshi, S.; Hashimoto, K. Inorg. Chem. 2000, 39, 5095. (b) Song, Y.; Ohkoshi, S.; Arimoto, Y.; Seino, H.; Mizobe, Y.; Hashimoto, K. Inorg. Chem. 2003, 42, 1848.

5. (a) Herrera, J. M.; BlTbzen, A.; Dromz, Y.; Julve, M.; Lloret, F.; Verdaguer, M. Inorg. Chem. 2003, 42, 7052. (b) Kashiwagi, T.; Ohkoshi, S.; Seino, H.; Mizobe, Y.; Hashimoto, K. J. Am. Chem. Soc. 2004, 126, 5024.

6. Prins, F.; Pasca, E.; Jongh, L. J. d.; Kooijman, H.; Spek, A. L.; Tanase, S. Angew. Chem. Int. Ed. 2007, 46, 6081.

7. (a) Benelli, C.; Gatteschi, D. Chem. Rev. 2002, 102, 2369. (b) Peruzzini, M.; Gonsalvi, L.; Romerosa, A. Chem. Soc. Rev. 2005, 34, 1038.

8. (a) Lin, P.-H.; Burchell, T. J.; Clérac, R.; Murugesu, M. Angew. Chem. Int. Ed. 2008, 47, 8848. (b) Lin, P.-H.; Burchell, T. J.;
Ungur, L.; Chibotaru, L. F.; Wernsdorfer, W.; Murugesu, M. Angew. Chem. Int. Ed. 2009, 48, 9489. (c) Wang, Y.; Li, X.-L.; Wang, T.-W.; Song, Y.; You, X.-Z. Inorg. Chem. 2010, 49, 969.

9. (a) Xu, G.-F.; Wang, Q.-L.; Gamez, P.; Ma, Y.; Clérac, R.; Tang, J.; Yan, S.-P.; Cheng, P.; Liao, D.-Z. Chem. Commun. 2010, 46, 1506. (b) Guo, Y.-N.; Xu, G.-F.; Gamez, P.; Zhao, L.; Lin, S.-Y.; Deng, R.; Tang, J.; Zhang, H.-J. J. Am. Chem. Soc. 2010, 132, 8538.

10. (a) Wang, J.; Xu, Y.-L.; Zhou, H.-B.; Wang, H.-S.; Song, X.-J.; Song, Y.; You, X.-Z. Dalton Trans. 2010, 39, 3489. (b) Wang, J.; Zhang, Z.-C.; Wang, H.-S.; Kang, L.-C.; Zhou, H.-B.; Song, Y.; You, X.-Z. Inorg. Chem. 2010, 49, 3101.

11. (a) Koziez, M.; Pezka, R.; Rams, M.; Nitek, W.; Sieklucka, B. Inorg. Chem. 2010, 49, 4268. (b) Pinkowicz, D.; Podgajny, R.; Nitek, W.; Rams, M.; Majcher, A. M.; Nuida, T.; Ohkoshi, S.; Sieklucka, B. Chem. Mater. 2011, 23, 21 .

12. (a) Hozumi, T.; Ohkoshi, S.; Arimoto, Y.; Seino, H.; Mizobe, Y.; Hashimoto, K. J. Phys. Chem. B 2003, 107, 11571. (b) Ikeda, S. Hozumi, T.; Hashimoto, K.; Ohkoshi, S. Dalton Trans. 2005, 2120. (c) Przychodzeń, P.; Lewiński, K.; Pełka, R.; Bałanda, M.; Tomala, K.; Sieklucka, B. Dalton Trans. 2006, 625.

13. (a) Prins, F.; Pasca, E.; Jongh, L. J. d.; Kooijman, H.; Spek, A. L.; Tanase, S. Angew. Chem. Int. Ed. 2007, 46, 6081. (b) Przychodzeń, P.; Pełka, R.; Lewiński, K.; Supel, J.; Rams, M.; Tomala, K.; Sieklucka, B. Inorg. Chem. 2007, 46, 8924. (c) Sutter, J.-P.; Dhers, S.; Rajamani, R.; Ramasesha, S.; Costes, J.-P.; Duhayon, C.; Vendier, L. Inorg. Chem. 2009, 48, 5820.

14. (a) Chelebaeva, E.; Larionova, J.; Guari, Y.; Ferreira, R. A. S.; Carlos, L. D.; Paz, F. A. A.; Trifonov, A.; Guérin, C. Inorg. Chem. 2008, 47, 775. (b) Chelebaeva, E.; Larionova, J.; Guari, Y.; Ferreira, R. A. S.; Carlos, L. D.; Paz, F. A. A.; Trifonov, A.; Guérin, C. Inorg. Chem. 2009, 48, 5983.

15. (a) Berlinguette, C. P.; Vaughn, D.; CańadaVilalta, C.; GalánMascarós, J. R.; Dunbar, K. R. Angew. Chem. Int. Ed. 2003, 42, 1523. (b) Shatruk, M.; Dragulescu-Andrasi, A.; Chambers, K. E.; Stoian, S. A.; Bominaar, E. L.; Achim, C.; Dunbar, K. R. J. Am. Chem. Soc. 2007, 129, 6104.

16. (a) Funck, K. E.; Hilfiger, M. G.; Berlinguette, C. P.; Shatruk, M.; Wernsdorfer, W.; Dunbar, K. R. Inorg. Chem. 2009, 48, 3438. (b) Funck, K. E.; Prosvirin, A. V.; Mathonière, C.; Clérac, R.; Dunbar, K. R. Inorg. Chem. 2011, 50, 2782.

17. Bok, L. D. C.; Leipoldt, J. D.; Basson, S. S. Z. Anorg. Allg. Chem. $\mathbf{1 9 7 5}, 415,83$.

18. Kahn, O. Molecular Magnetism; VCH Publishers: New York, 1993.

19. Sheldrick, G. M. SADABS An empirical absorption correction program, Madison, WI, Bruker Analytical X-ray Systems, 1996.

20. Sheldrick, G. M. SHELXL-97; Program for refinement of crystal structures, University of Göttingen, Germany, 1997.

21. Tang, J.; Hewitt, I.; Madhu, N. T.; Chastanet, G.; Wernsdorfer, W.; Anson, C. E.; Benelli, C.; Sessoli, R.; Powell, A. K. Angew. Chem. Int. Ed. 2006, 45, 1729. 